\title{
Karonese Nganting Manuk (NM) Text Translation Into English
}

\author{
Farida Repelita Waty Kembaren, Hum, Ph.D. student, \\ Dr. Syahron Lubis, M.A., lecturer, \\ Dr. Umarmono, M. Hum, lecturer, \\ Dr. Muhizar Muchtar, M.S., lecturer \\ Linguistic Department, University of North Sumatra (USU), Medan, North Sumatra, Indonesia
}

\begin{abstract}
The use of pure borrowing techniques to translate cultural content text aims to maintain cultural values contained in the source text, but the meaning of the text may not be conveyed in the target text. Nganting Manuk text is one of the cultural Karonese cultural texts which are used in the wedding ritual of Karonese Community. Translation error on the cultural content can damage the meaning and cultural values contained therein. Therefore, this study aimed to find a translation of the meaning and cultural issues in $N M$ text translation, technical translation of the corresponding applied to translate the $N M$ text, as well as to determine the quality of $N M$ text. Therefore, this study was conducted to find the most appropriate translation techniques used to translate a cultural content text-Nganting Manuk. Analysis was performed on a text which has been translated from Karo into English. The analysis showed that pure borrowing technique is the most appropriate technique to be used to translate a text-laden culture. The use of pure borrowing techniques in cultural content in Nganting Manuk text can clarify the meaning and cultural values of the source text into the target text. As the analysis result, it was found that the technique of Cultural Philosophy and Contextual Information (CPCI) is the proper technique to translate cultural content $N M$ text.
\end{abstract}

Keywords: problems found, mechanical translation, quality translation, $N M$ text

\section{Introduction}

$N M$ text is a text used in one stage Karonese ritual prior to the wedding ceremony. This is the stage where families of the bride and groom to discuss the dowry to be received by the bride. The $N M$ text has been summarized in a book called Adat Karo compiled by Darwan Prints and published by Bina Media Pioneers in 2012. The text has been translated into English by a translator practitioner who understands the language and culture of Karo and English. The translation of the $N M$ text has been selected as the object of study in this research. The research on the translation of $N M$ texts is important to maintain the cultural value and meaning of the text of the cultural content. The findings of this study can be useful to overcome the problem of translating text translation in cultural content such as text $N M$.

Farida Repelita Waty Kembaren, Hum, lecturer, Ph.D. student, Linguistics Department, University of North Sumatra (USU). E-mail: Faridauin@gmail.com.

Dr. Syahron Lubis, M.A., lecturer, Linguistics Department, University of North Sumatra (USU). E-mail: ronlubis@gmail.com.

Dr. Umarmono, M. Hum, lecturer, Linguistics Department, University of North Sumatra (USU). E-mail: umar mono@yahoo.com.

Dr. Muhizar Muchtar, lecturer, M.S., Linguistics Department, University of North Sumatra (USU). E-mail: muhizarm@yahoo.com. 
Examples of translation problems in the translation of the $N M$ text is to eliminate the cultural values of text, for example nakanbaluten phrase which literally means wrapped rice which translates into wrapped rice by the translator. Target text readers will be able to understand the meaning of the phrase nakanbaluten when given a description of what the nakanbaluten (Nakanbaluten is a kind of steamed rice wrapped in a round shape). In this way, the target audience may be able to understand that nakanbaluten is rice cooked and wrapped and molded into a round shape, but the target audience is not necessarily able to understand the cultural values in the text if the phrase is translated only by providing an explanation of the meaning of that phrase (amplification techniques) because readers target does not get specific information about cultural values and philosophy contained in the foods served in the $N M$ customary rituals.

To cope with translation errors in the $N M$ text, researchers are interested in analyzing the $N M$ text translation into English in order to find the problems translations that appear in the results of $N M$ text translation, techniques of translation contained in $N M$ text translation, as well as the quality of the translated text NM. This study focused on words, phrases, and sentences contained in the text translation $N M$ as the analysis of the translation techniques will be related to the smaller units such as the words and phrases (Molina \& Albir, 2002, p. 509).

The findings of this study are very useful to improve the quality of translations, particularly in the field of cultural translation. One example of the cultural content of text is $N M$ text conversation. Problems and approprieate translation techniques used to translate the $N M$ text will be a reference for translators to improve the translation quality.

\section{Literature Review}

Bronislaw Malinowski (1965) provides a definition of translation as follows: "Translation must always be the recreation of the original into something profoundly different On the other hand, it is never a substitution of the word but inevitably the translation of whole context" (pp. 11-12).

In translation definitions put forward by Malinowski above, Malinowski saw translation as an effort to regenerate the source text into something different where the translation is not a mere replacement of the word, but it is the overall context of the translation. In that sense, Malinowski argued that in conducting the business of translation, a translator not only served to replace the words in the source text as opposed to the words contained in the text of the targets, but a translator must be able to translate the entire context contained in the source in the text to the target text.

Bronislaw Malinowski has experienced problems in translating the social event of verbal ceremonies Melanesian population into English. When he uses the free translation, he found that the meaning of the source text can be understood by readers of the target of the text, but the text of cultural values cannot be delivered. Then, he tried to use literal translation techniques, and he found that the text of cultural values can be well, but the meaning of the text is less understood by the target text reader. Thus, he decided to supplement the translation of the comments used as a bridge to bring the situation of the text. Since that time, he believed that a text cannot be understood without understanding the context of the situation of the text itself (Hatim \& Mason, 1990, pp. 36-37).

This is in accordance with the opinion of Larson stating that the translation is not merely an accurate portrayal of the meaning but also pay attention to the communication situation and the context of the culture of the language (Larson, 1984, p. 3) where it is the task of a translator to the make the reader the target text to understand the meaning of the source text and the context of the language appropriately in the targeted text. 
Larson $(1984$, p. 3) also added that the translation includes an understanding of the vocabulary, grammar, communication situation, as well as the cultural context of the source language. So to the make an effort of translation, a translator must understand the vocabulary, the structure of language, communication situations both language, and cultural contexts.

In doing translation of text cultural content such as text $N M$, the translator is sure to find problems in translating text conversation $N M$ into English. The problems of translation can be a word that has more than one meaning (ambiguous), difficulties in seek equivalent idiom contained in the source language into the target of language, then there is a word in the source language that is hard to find equivalent corresponding to the targeted language, in addition to translation problems caused by differences in the structure of the language and culture of the two texts. Therefore, the use of techniques the proper translation would be a way to address the issue.

Molina and Albir (2002) defines a translation technique as a procedure to analyze and classify how equivalence translation in progress and can be applied to various units lingual (p. 509). The following are the translation techniques proposed by Molina and Albir (2002):

Literal translation techniques are: (1) borrowing; (2) calque; and (3) literal translation.

Oblique translation techniques are: (1) transposition; (2) modulation; (3) equivalence; (4) adaptation; (5) compensation; (6) concentration versus dissolution; (7) amplification versus economy; (8) reinforcement versus condensation; (9) explicitation versus implicitation; (10) generalization versus particularization; and (11) inversion.

The use of techniques of translation will affect the quality of the translated $N M$ text content, therefore, the quality test needs to be done to avoid errors. In assessing the quality of the translation, there are several factors that need be considered (Larson, 1984), which are as follows:

(1) Accuracy items, namely to check whether the messages in the source text is in conformity with the meaning in the target text;

(2) Acceptance, which is to see the translation results that feel natural in the text by using commonly used terms, as well as the use of words and sentences in accordance with the rules of the target language;

(3) Readability, which is to read the text with ease where the meaning of the translated text results is easily understood by the target text reader.

\section{Research Methodology}

This research uses descriptive qualitative research methods. Included in this type of research are descriptive-qualitative oriented on the translation products. Translation of research focusing on the translation work, like the opinion of the researchers who believe that the translation is supposed to be focusing on translation products (Toury, 1980) instead of focusing on the translation process. The main data of this study is in the form sentences conversations contained in the text of the indigenous book of $N M$ Karo compiled by Darwan Prints and published by Bina Media Pioneers in 2012, which has been translated into English.

The technique used to determine the sample in this study aims at engineering sample (purposive sampling technique) in which the sample is determined in accordance with the purpose of research. The main data source of this study is in the form of sentences of $N M$ text conversation which have been translated into English from Karonese. 112 sentences conversation on this text were chosen. Analysis on the sentences aimed to identify the problems of translation, translation techniques, the most appropriate translation techniques applied, as well as the quality of the translation of the text $N M$ has been translated into English. Then the next research of data are key informant statements on the quality of the translation. 


\section{Findings and Discussion}

After conducting an analysis in the study sample, the obtained results as follows:

\section{Translation Issues}

After analyzing the data within the 112 text translation $N M$, it is found that there are 64 translation problems that cause text cultural value is not delivered, five translation problems that cause the meaning of the text is not delivered, and 42 data are not problematic.

Cultural values text only partially. There are 65 data that have problems because cultural text is not delivered. Text cultural value is not delivered due to the fact that there is no explanation of the cultural values of the words within the text. Example:

Text source: Eakkam our kalimbubu, nindudageugangeperpulung us?

Target text: You are our Kalimbubu, what do you think about our family?

* Note: Kalimbubu is the bride's family.

In the example above text, translators use borrowing and amplification techniques to explain the meaning of the word kalimbubu. Target audience will understand the meaning of the word kalimbubu by reading the notes given by an interpreter, but the target audience will not be able to understand the cultural values in the text NM. Target readers will not understand that what kalimbubu role in the ritual NM. Therefore, the above text is problematic because the meaning of the text is delivered, but the value of culture and philosophy texts cannot be delivered.

Text source: Eakkam our kalimbubu Sebayangmergana, ninduperpulungberundu our children?

Target text: You are our Kalimbubu clan Sebayang, do you mean that we, your Son Beru, have been present here?

* Note: MargaSebayang is one kind of Clans in Karonese family system. Beru child is the bridegroom's family.

In the above example, the translator uses the technique of borrowing to translate phrases and Marga Children Beru Sebayang. Furthermore, the translator also using amplification techniques to provide additional explanations on Children.

Beru and Merga said Sebayang. In this case, the translator managed to keep the cultural values of the source text with no change in cultural terms of the source language (Children Beru and Marga Sebayang) in the target language, then translators can also convey the meaning of the source text in the target language by providing additional explanation to the term cultural. However, the translator has not managed to convey the cultural values of the source text in the target text. Target audience will understand the meaning of the text, but not necessarily be able to understand the cultural values contained in the text of the translation of the cultural content.

Text meaning only partially. Five data have problems because the text's meaning is not conveyed. Meaning of the text is not delivered due to the fact that there is no explanation of the meaning of words in the text. In other words, translators using translation techniques instantly without giving an explanation will be words. Example:

Text source:

Acarantapagibagenda:

This is the schedule of our events:

8:00 to $9: 00 \mathrm{pm} \quad$ breakfast in this jambur

9:00 to 10:00 get dressed in this jambur 


$\begin{array}{ll}\text { 10:00 to } 11: 00 & \text { presenting gold } \\ \text { 11:00 to } 13: 00 & \text { advices/dance } \\ 13.00 & \text { lunch }\end{array}$

What do you think?

Target text:

Acarantapagibagenda:

This is the schedule of our events:

$\begin{array}{ll}\text { 8:00 to } 9: 00 \mathrm{pm} & \text { breakfast in this jambur/hall } \\ \text { 9:00 to } 10: 00 & \text { get dressed in this jambur/hall } \\ \text { 10:00 to } 11: 00 & \text { presenting gold } \\ \text { 11:00 to 13:00 } & \text { advises/Landek } \\ \text { 13.00 } & \text { lunch }\end{array}$

What do you think?

In the above example, the translator did not provide equivalent words of the source text in the target text. Translators used the technique of pure borrowing and did not provide an explanation as additional information to explain the meaning of these words. Therefore, the meaning of the text cannot be conveyed to the target audience. Target audience will not be able to understand the meaning of the above.

Based on the results of the analysis, we concluded that the errors most often occurring in the $N M$ text translation from Karo language into English are translation problems that cause only partially on the cultural value of the text. Thus, the overall percentage of translation problems contained in the translated $N M$ text is as follows:

Text cultural values are not delivered:

$X^{-}=65 / 112 \times 100 \%$

The meaning of the text is not conveyed:

$\mathrm{X}=5 / 112 \times 100 \%$

$\mathrm{X}=4.5 \%$

No problem:

$\mathrm{X}=42 / 112 \times 100 \%$

$X^{-}=37.5 \%$

The following figure will clarify the percentage of translation problems in the $N M$ text:

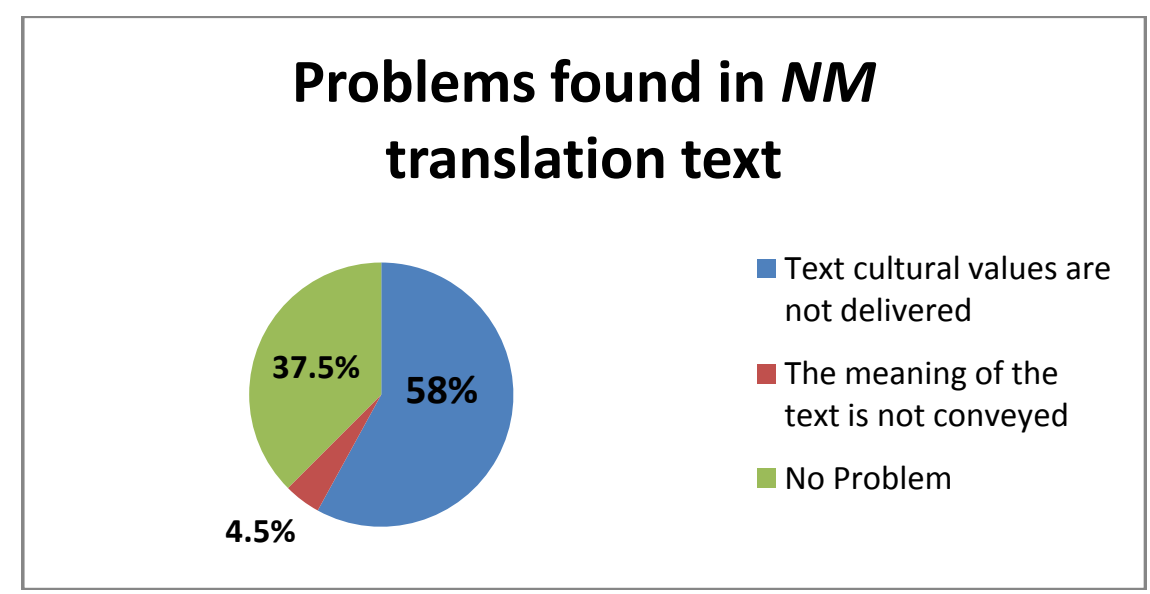

Figure 1. Problems found in $N M$ translation text. 


\section{Translation Techniques}

After conducting an analysis of 112 data in $N M$ translation text, there were 70 times pure borrowing techniques, 64 times amplification techniques, 22 times literal techniques, 19 times transposition techniques, 14 times reduction techniques, five times the technique of equivalence, and two times the modulation techniques. Thus, it can be seen that the borrowing and amplification techniques are the most dominant technique used in the $N M$ translation text.

The use of pure borrowing techniques aimed at preserving the cultural value of the text by borrowing directly terms of cultural content from the source language to the target language. Here is an example of using the technique of borrowing on the $N M$ text:

Text source: Eakkam our kalimbubu, nindudageugangeperpulung us?

Target text: You are our Kalimbubu, what do you think about our family?

By using the technique of borrowing, the terms of such cultural content, kalimbubu can be maintained and displayed in the target text in order that the cultural value of text is also conveyed and not lost. However, the target audience will find it difficult to understand the meaning of the target text because there is no explanation of the meaning of the term culture kalimbubu in the target text. Despite the cultural values of text can be maintained, it still will cause the text's meaning cannot be delivered to target audience. Therefore, the required use of amplification techniques to provide an explanation of the cultural content terms is contained in the target text.

Amplification is a technique that paraphrases implicit information in the source language into the target language; this technique introduces detailed information or explicit information that is not contained in the source text. This technique is used to translate a phrase which has no equivalent in the target language, such as: sarongs, batik, and gado-gado. To translate phrases like these, translators need to provide additional records in order to realize the meaning of the source text so that the reader can understand the text in the target. These records can be given as footnotes or endnotes. Here is an example of using amplification techniques:

Text source: Eakkam our kalimbubu, nindudageugangeperpulung us?

Target text: You are our Kalimbubu, what do you think about our family?

* Note: Kalimbubu is the bride's family.

By using amplification techniques, such cultural terms, kalimbubu can be maintained and displayed in the target text so that the cultural value of the source text is not lost. In addition, the target audience is not difficult to understand the significance of the target text for it provided an explanation of the meaning of the term culture kalimbubu in the target text in the form of footnotes (footnotes). Despite the fact that the cultural values of text can be maintained and the meaning of the cultural content terms can be understood from the explanation given in the footnotes, target audience will not be able to understand the philosophy of the cultural value of cultural content of the text. Because in the cultural content of the translation text, the translator is not only responsible to convey the meaning of the text, but also can convey the cultural values implicit in the text of the cultural content.

This refers to the views of Hoed about translation problems. He argues that there are two main problems in the translation into a foreign language, namely, differences in both languages and differences of the two cultures (Hoed, 2006). Language differences can be overcome by using amplification techniques to provide additional explanations of the meaning of a word, but not the cultural differences. By using the technique of 
pure borrowing and amplification, translator will be able to convey the meaning of the text and also maintaining the cultural values of the source text, but the translator not only needs to maintain the cultural value of text only, translators must also be able to convey the cultural values of the source text in the target text so that readers can not only understand the target is the meaning of the text but also the cultural values contained in a text-laden culture. Therefore, the use of borrowing and amplification techniques are still not enough to be able to translate text-laden culture well. Translators need to use a technique to convey the philosophy of a text value cultural content such as $N M$.

Cultural Philosophy Information (Information Engineering Philosophy and Culture) is a suitable technique used to translate any cultural text and content so that readers can understand the meanings simultaneously, i.e., cultural text values and content. Here is an example of the use of information technology philosophy of culture:

Text source: Eakkam our kalimbubu, nindudageugangeperpulung us?

Target text: You are our Kalimbubu, what do you think about our family?

Amplification: Kalimbubu is the bride's family.

* CPI (Cultural Philosophy Information): In Karonese wedding tradition, wedding party will be held in kalimbubu house.

This technique can be used to assist in the amplification technique of borrowing and text translation of cultural content. In the example above, using target amplification techniques, the reader will understand the meaning of the term culture kalimbubu, but does not necessarily understand what the role kalimbubu in custom wedding ceremony Karo- $N M$. Using the technique of Cultural Philosophy Information, target audience not only know the meaning of the term culture, but also know the meaning of a term cultural philosophy because not all cultural content terms have the meaning according to the actual role. In the example above, the term culture kalimbubu translated by using the techniques of cultural philosophy is inclusive information. In Karonese wedding tradition, wedding party will be held in kalimbubu house. By giving this explanation, target audience will understand the meaning of the term culture philosophy of kalimbubu. Target audience will understand that in a wedding ceremony of Karo indigenous communities, the wedding party will be held in house kalimbubu - the bride's family home. Here are a few examples of the use of techniques Cultural Philosophy Information technique to translate text $N M$ cultural content:

Text source:

Dagesope our benakenrunggunenda, pasehndudage man puangkalimbubu gelahtertinggel-tinggel he lebe.

Target text:

So, before we start this ritual, please remind PuangKalimbubu to pay attention.

* CPI: In NM ceremony, PuangKalimbubu will be a person from the bride's family given responsibility to lead a discussion.

Text source:

Adi bagels arihkamkalimbubunta race, enggo me sissy pedalanKampil enda?

Target text:

Then, we may share this Kampil?

* CPI: Kampil is a box filled of ingredients and tools for such as betel chewing betel leaf, areca nut, gambier, and etc. Kampil is usually presented as a symbol of honor and appreciation to the guess in Karo society, and in NM Kampil ceremony is presented before starting the discussion. 


\section{Translation Quality}

In this study, the quality of the translation $N M$ text has been translated into English based on aspects of accuracy, acceptability, as well as aspects of legibility. By knowing the quality of the translated $N M$ text, translators can make improvements by improving the quality of the translation.

After analyzing the 112 the data, it was found that the results in the accurate translation of $N M$ text translation are as many as 105 data, while the results in less accurate translation of $N M$ text are as many as seven data. The average percentage rate quality of $N M$ text accuracy can be calculated by using the following formula:

The translation is accurate:

$$
\begin{aligned}
X & =105 / 112 \times 100 \% \\
& =93.7 \%
\end{aligned}
$$

The results are less accurate translation:

$$
\begin{aligned}
X^{-} & =7 / 112 \times 100 \% \\
& =6.25 \%
\end{aligned}
$$

Thus, the accuracy of the translated $N M$ text can be seen in the following figure:

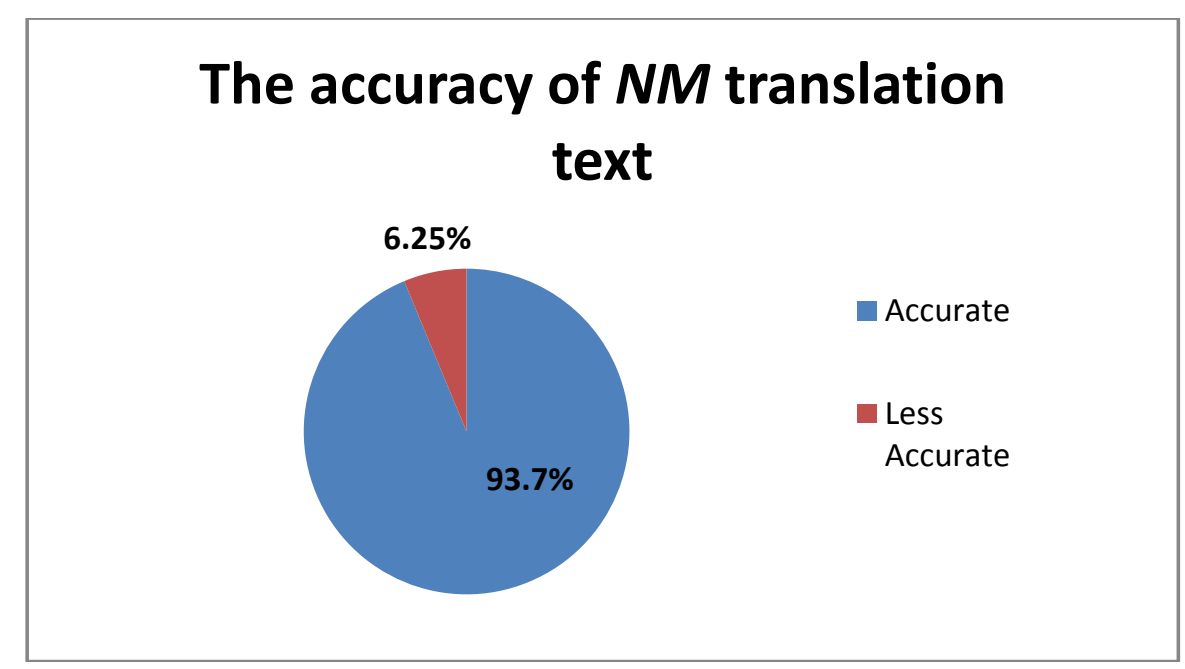

Figure 2. The accuracy of $N M$ translation text.

After analyzing the 112 the data, it was found that the translated $N M$ text are accurate as many as 42 data, while the results of less acceptable translation in $N M$ text translation are as many as 70 data. The average percentage of acceptance level quality of $N M$ text translation can be calculated by using the following formula:

The translation is acceptable:

$$
\begin{aligned}
X & =42 / 112 \times 100 \% \\
& =37.5 \%
\end{aligned}
$$

The translation is less acceptable:

$$
\begin{aligned}
X^{-} & =70 / 112 \times 100 \% \\
& =62.5 \%
\end{aligned}
$$

Thus, the level of acceptability of the translated text $N M$ can be seen in the following figure: 


\section{The level of acceptance of NM translation text}

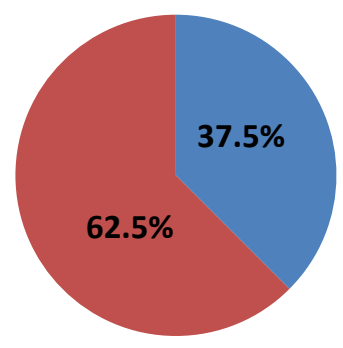

Acceptable

Less

Acceptable

Figure 3. The level of acceptance of $N M$ translation text.

After analyzing the 112 the data, it was found that the translated $N M$ text with high readability level is as many as 42 data, while the translated text $N M$ with moderate readability level is as much as 70 data. The average percentage rate of quality text readability $N M$ translation can be calculated by using the following formula:

Translated results with a high level of readability were:

$$
\begin{aligned}
X & =42 / 112 \times 100 \% \\
& =37.5 \%
\end{aligned}
$$

Translated results by reading level were:

$$
\begin{aligned}
\mathrm{X}^{-} & =70 / 112 \times 100 \% \\
& =62.5 \%
\end{aligned}
$$

Thus, the readability level of $N M$ text translation results can be seen in the following figure:

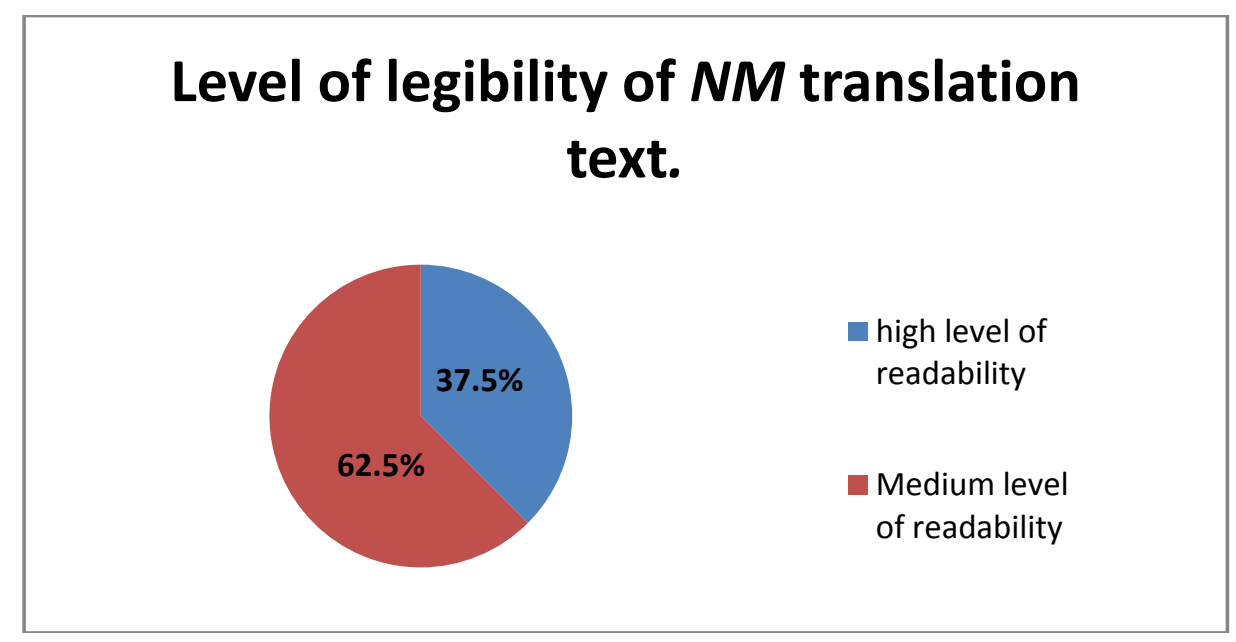

Figure 4. Level of legibility of $N M$ translation text.

Based on the results of the analysis, it was found that the factors that need to be corrected to improve the quality of $N M$ text translation from Karo language into English are at the level of acceptability and legibility of $N M$ text. 


\section{Conclusion}

By knowing the faults in the translation of $N M$ text, the translation techniques are most appropriate and the factors that need to be fixed to improve the quality of $N M$ text from Karo language into English, the translator will be able to tackle issues which often happen by using the most appropriate translation techniques used in translating the $N M$ text from Karo language into English, so the translator will be able to improve the quality of the translation of the $N M$ text. These findings will be useful for translators to improve the quality of the translation that messages and cultural values in the translated $N M$ text can be maintained and understood by the target audience. Thus, the tradition of Karo ethnic communities will be introduced well to the target audience.

\section{References}

Arikunto, S. (2010). Prosedur Penelitian Suatu Pendekatan dan Praktik (A research procedure: An approach and practice). Jakarta: Rineka Cipta.

Baker, M. (1992). In other words: A coursebook on translation. London: Sage Publication.

Bell, R. T. (1991). Translation and translating: Theory and practice. New York: Longman.

Brislin, R. W. (Ed.). (1976). Translation: Application and research. New York: Gardner Press, Inc..

Catford, J. C. (2005). Translation shift. In L. V. Dalam (Ed.), The translation studies reader. London and New York: Routledge.

Chisholm, H. (Ed.). (1911). Bride. Encyclopædia Britannica (11th ed.). Cambridge: Cambridge University Press. Retrieved from https://en.wikipedia.org/wiki/White_wedding\#The_reception

Ginting, S. A. (2007). Kesantunan dalam Perkawinan Nganting Manuk (Marriage customs of politeness in Nganting Manuk). Jurnal Linguistik Terapan Pascasarjana Unimed, 4(2), 21-28.

Hafiz, A. (2010). Analisis Tehnik Penerjemahan dan Kualitas Terjemahan Buku Asal Usul Elit Minangkabau Modern: Respons terhadap Kolonial Belanda Abad XIX/XX (Translation techniques analysis and translation quality books of elit of modern Minangkabau origins: The response to the XIX/XX century Dutch colonial) (Thesis, Pascasarjana Program Megister Linguistik, Minat Utama Penerjemahan, Universitas Sebelas Maret, Surakarta).

Hartono. (2000). Studi tentang Metode Terjemahan yang digunakan Mahasiswa Jurusan Pendidikan Bahasa Inggris Universitas Muhammadiyah Malang (The study on translation methods used by the students of English Education Department, $\begin{array}{lllll}\text { University } & \text { of } & \text { Muhammadiyah } & \text { Malang). }\end{array}$ http://digilib.itb.ac.id./gdl/php?mod=browse\&op=read\&id=jiptumm-gdl-res-2000-hart

Hatim, B. (2013). Teaching and researching translation. Harlow: Pearson.

Hatim, B., \& Mason, I. (1990). Discourse and the translator. London and New York: Longman.

Hoed, B. H. (2006). Penerjemahandan Kebudayaan (Translation and Culture). Bandung: Pustaka Jaya.

Larson, M. L. (1991). Translation: Theory and practice, tension and interdependence. New York: Univ. Press.

Larson, M. L. (1984). Meaning-based translation: A guide to cross-language equivalence. New York: Univ. Press.

Lubis, S. (2009). Penerjemahan Mangupa dari bahasa Mandailing ke dalam bahasa Inggris (The translation of Mangupa from Mandailing language into English) (Doctoral dissertation. Sekolah Pascasarjana, USU Medan).

Machali, R. (2009). Pedomanbagipenerjemah: panduanlengkapbagianda yang inginmenjadipenerjemah professional (Guidelines for translators: The complete guide for those of you who want to become professional translators). Bandung: Penerbit Kaifa.

Malinowski, B. (1969). A scientific theory of culture and other essays. New York: Oxford University Press.

Miles, M. B., \& Hubberman, A. M. (1984). Qualitative data analysis. London: SAGA Publication.

Molina, L., \& Albir, A. H. (2002). Translation technique revisited: A dynamic and functional approach. Meta, 47(4), 498-512.

Muhammad. (2011). Metode Penelitian Bahasa (Language research methods). Jogjakarta: Ar-Ruzz Media.

Munday, J. (2012). Introducing translation studies: Theories and applications. London and New York: Routledge.

Nababan, M. R. (2004). Translation processes, practices and products of professional Indonesian translators. New Zealand: Victoria University of Wellington.

Nababan, M. R. (2004). Strategi Penilaian Kualitas Terjemahan (Translation quality assessment strategies). Jurnal Linguistik Bahasa, 2(1), 54-65. 
Nasution, H. P. (2011). Penerjemahan Teks Marpokat Haroan Boru dalam Perkawinan Adat Mandailing dari Bahasa Mandailing ke dalam Bahasa Inggris (The translation of Marpokat Haroan Boru Text in indigenous Mandailing marriage from Mandailing language into English) (Thesis, Pascasarjana USU Medan).

Newmark, P. (1988). A textbook of translation. New York and London: Prentice-Hall International.

Nida, E. A. \& Taber. (1982). The theory and practice of translation. Leiden: E. J. Brill.

Nida, E. A. \& Taber. (1974). The theory and practice of translation. Leiden: E. J. Brill.

Prints, D. (2002). Kamus Karo Indonesia. Medan: Bina Media Perintis.

Prints, D. (2012). Adat Karo. Medan: Media Perintis.

Rizky, P. (2008). A study of grammatical cohesion: Reference in the discourse of Nganting Manuk in Karonese traditional wedding ceremony (Thesis, USU, Medan).

Sadtono, E. (1985). Pedoman Penerjemahan (Translation guidelines). Jakarta: Pusat Pembinaan dan Pengembangan Bahasa, Depdikbud.

Salleh, M. H. (2006). Romance and laughter in the archipelago essays on classical and contemporary poetics of Malay world. Pulau Pinang: University Sains Malaysia.

Sembiring, M. (2014). Translating themes of Rebu texts in Karonese society into English (Unpublished Ph.D. dissertation, University of Sumatera Utara, Medan).

Sembiring, B. (2008). Musik dalam Upacara Perkawinan Adat Masyarakat Karo: Fungsi Gendang Laradat Pasca Acara Nganting Manuk (Music in the marriage ceremony of indigenous people of Karo: Function of the "Gendang La radat" post event of "Nganting Manuk") (Thesis, Pasca Sarjana Unimed).

Silalahi, R. (2009). Dampak Teknik, Metode, Dan Ideologi Penerjemahan Pada Kualitas Terjemahan Teks Medical-Surgical Nursing Dalam Bahasa Indonesia (The impact of techniques, methods, and translation ideology in translation quality of medical-surgical nursing text in Indonesian) (Dissertation, Pasca Sarjana USU).

Sorvali, I. (1996). Translation studies in a new perspective. Frankfurt am Main: Peter Lang.

Surbakti, H. (2016). Documentation and translation techniques of traditional Karonese medical text on fractured bone setting (Dissertation, Pasca Sarjana USU, Medan).

Suryawinata, Z. D. S. H. (2003). Translation (Bahasan Teori \& Penuntun Praktis Menerjemahkan). Jakarta: Kanisius.

Sutopo, H. B. (2002). Metodologi Penelitian Kualitatif, Dasar Teori dan Terapannya dalam Penelitian (Qualitative research methodology, basic theory and its application in research). Surakarta: Sebelas Maret University Press.

Sutopo, H. B. (2006). Metodologi Penelitian Kualitatif, Dasar Teori dan Terapannya dalam Penelitian (Qualitative research methodology, basic theory and its application in research). Surakarta: Universitas Sebelas Maret.

Venuti, L. (1995). The translator's invisibility: A history of translation. London: Routledge.

"Vigselakten" wedding ceremony brollopstorget.se. In Today's most common in Sweden and the groom in the church together.

Vinay, J. P., \& Darbelnet, J. (2000). A methodology for translation. In D. L. Venuti (Ed.), The translation studies reader (2nd ed.). London and New York: Routledge.

Wills, W. (1996). Knowledge and skills in translator behavior. Amsterdam: John Benjamins.

Woollams, G. (2004). Tata Bahasa Karo (Karonese grammar). Medan: Bina Media Perintis.

Yusmaniar, Cs. (1987). Struktur Bahasa Karo (Karonese language structure). Jakarta: Pusat Pembinaan dan Pengembangan Bahasa, Departemen Pendidikan dan Kebudayaan (Training and Language Development Center, Ministry of Education and Culture). 